\title{
Why I banned a book \\ How censorship can impact a learning community
}

"Heresy was good: heresy meant opportunity."-Moneyball: The Art of Winning an Unfair Game by Michael Lewis ${ }^{1}$

$\mathbf{Y}$ es, I banned a book. I am a seasoned librarian and academic library director and a supporter of free speech and democracy, ${ }^{2}$ but I banned a book. The term heresy quickly comes to mind in the world of librarianship, but the story is much deeper than it first appears. The very temporary banning was simply an object lesson to our campus community on the arbitrary and capricious nature of censorship, as well as providing an interesting take on the nature of social media.

The story begins with two staff members and one librarian who enthusiastically created and ran a week of interactive programs for banned book week. The turnout was tepid. A panel discussion on the subject drew six people. Five were librarians and staff members. The sixth was Dennis Miller, our public relations director, who recently published his second novel, One Woman's Vengeance. As we talked about various books that are still being banned at different locations around the country, Miller said, "You should ban mine. It has sex, violence and adult language."

He was joking, but his statement emphasized that as long as one book can be banned, any book is a target.

Two of my staff members and one librarian thought it over and came to me a couple days later, suggesting that we should, indeed, ban it during Banned Books
Week. We talked over the ramifications and I agreed. We contacted Miller, an ardent opponent of censorship.

He agreed to participate. ${ }^{3}$

Only five of us knew about the project.

Our thought was that over the years, the subject of banned books had outlived any sense of uniqueness or urgency. It had become just another cause talked about once a year, usually by a display of banned books that to most people, especially college students, is just abstract.

Miller enjoys a good deal of popularity on our campus and in our Northern Tier area. The book, with its female protagonist, is set in the Old West and uses profanity and violence to portray the plight of women during this era. In fact, it is a gutsy allegory on feminism and the human condition. The book had received a lot of press, excellent reviews, and has a good following.

By using a familiar and well-liked local author, the sharp point of what harm censorship can really do to a community could be driven home in a way that it never could with the standard list that we all hang up every year.

I made the announcement-a simple two-sentence memo (on letterhead), placed on our Facebook wall. The angry reaction from students, faculty, alumni, and other "interested parties," was immediate. A local

Scott R. DiMarco is director of library and information resources at Mansfield University of Pennsylvania, e-mail: sdimarco@mansfield.edu

(c) 2013 Scott R. DiMarco 
newspaper reporter contacted Miller within 20 minutes of the posting. A Facebook protest page was created within a day and people from around the country were voicing their angry thoughts. One person even posted that he didn't know books were still being banned.

We had gotten people's attention.

We also stimulated their indignation and outrage that this, or any other, book would be banned by a college library.

The less positive outcome, in my mind, was that on a campus of 3,000, only eight people actually asked for a meeting with me to discuss the reasons I banned the book and to discuss what could be done to reverse the ban. The overwhelming number of comments were complaints about how they felt betrayed by this action or their frustration with the administration. Some used Facebook as a forum to make rude comments from the relatively safe distance social media provides.

Two days after the announcement of the banning, we revealed the truth. The reaction was overwhelmingly positive. People posted comments such as "Well, played, Mansfield, well played" and "Great job, librarians. You would make Noah Wyle proud. You really ARE super heroes. Kudos to all involved."

In conclusion, a typical set of programs on the topic of censorship were met by our campus community with general apathy and pleasant indifference. Our unorthodox (okay, heretical) experiment was very successful in highlighting how a simple bureaucratic decision can curb our freedom to read.

In the library world, access to information is a human right, not to be tampered with, not to be controlled in any way.

In his blog, Miller pointed out, "No book has ever been universally banned on a permanent basis." ${ }^{4}$

A few people have called this lesson unethical, but the really unethical part of what happened here was that many people simply sat back and said nothing in the

\section{Our thought was that over the years, the subject of banned books had out- lived any sense of unique- ness or urgency.}

face of the outright suppression of a book. I applaud the people-mostly college students-who acted in a constructive and respectful manner to address this censorship issue by their courageous actions in working through the system to have the ban lifted.

The experience was both exhausting and exhilarating.

Sometimes you have to kick-start the intellect with a good boot to the emotion. ${ }^{5}$

\section{Notes}

1. Michael Lewis, Moneyball: The Art of Winning an Unfair Game (WW Norton \& Company, 2004).

2. American Library Association statement on the Freedom to Read, www.ala. org/advocacy/intfreedom/statementspols /freedomreadstatement.

3. All royalties from Dennis Miller's two books, One Woman's Vengeance and The Perfect Song, go to an endowed scholarship to the Mansfield University English Department.

4. "Ban my Book. Please!" A blog by Dennis Miller on the Huffington Post, www.huffingtonpost.com/dennis-miller/ ban-my-book-please_b_1933551.html, retrieved June 6, 2013

5. A special thanks is given to those who actively supported our fight against censorship: Nicole Book, Amanda Sanko, Pam Achey, and Jamey Harris all of the North Hall Library at Mansfield University. Alan Golden, interim president of Mansfield University, and especially Dennis Miller, director of public relations at Mansfield University. $\boldsymbol{n}$ 